\title{
PERUBAHAN FUNGSI RUANG RUMAH KUNO DI KAMPUNG KAUMAN SURAKARTA
}

\author{
Didik Darmadi, Dhani Mutiari \\ Program Studi Teknik Arsitektur, Fakultas Teknik, Universitas Muhammadiyah Surakarta \\ Jl. A. Yani Tromol Pos 1 Pabelan Kartasura Sukoharjo 57102 Telp 0271-717417 \\ E-mail: dhani.mutiari@yahoo.com
}

\begin{abstract}
ABSTRAK
Perjalanan waktu membuat Kauman yang berada dekat dengan Jalan Slamet Riyadi menjadi semakin ramai. Rumah tinggal di masa lalu telah banyak berubah fungsi. Penelitian ini membahas tentang keragaman perubahan fungsi ruang di rumah lama yang berada di wilayah Kauman. Literatur yang digunakan terkait dengan difinisi perubahan dan rumah tradisional Jawa yang berada di Surakarta. Metode yang digunakan adalah deskriptip kualitatip dengan pencarian data secara survey dan wawancara terhadap 7 rumah kuno di Kauman. Hasil dari penelitian ini adalah perubahan fungsi ruang yang terbesar meliputi pendapa dengan prosentase $66.67 \%$, kemudian diikuti gandok dengan prosentase 50\%. Disamping dari jenis ruang diatas juga terdapat faktor-faktor penyebabnya yang meliputi faktor internal dan faktor eksternal. Di dalam faktor internal prosentase terbesar adalah skill dan kebutuhan ekonomi yang mempunyai kedudukan yang seimbang yaitu $29 \%$. Kemudian untuk faktor eksternal didominasi untuk perkembangan usaha yang mencapai 37\%, kemudian diikuti letak yang strategis dan melestarikan budaya batik dengan prosentase sebesar $27 \%$.
\end{abstract}

Kata Kunci: rumah kuno, perubahan, fungsi

\section{PENDAHULUAN}

Menurut Setyoningsih (1999) Kauman adalah salah satu Kampung Lama di Surakarta. Kauman mulai tumbuh saat Paku Buwono III membangun Masjid Agung pada tahun 1757 M, Sang Raja mengangkat Tafsir Anom sebagai Penghulu Masjid Agung. Dalam melaksanakan tugas sehari-harinya penghulu Masjid Agung dibantu oleh Abdi Dalem Ulama lainnya (yaitu Ketib, Merbot dan Berjamaah). Para abdi dalem ulama beserta para Santri tinggal di sekitar Masjid Agung yang kemudian berkembang dan dinamakan "Kauman" yang berarti kampung "kaum".

Kauman juga merupakan kampung batik di Surakarta setelah Laweyan. Tradisi batik Kauman mewarisi secara langsung inspirasi membatik dari dalam Kraton Kasunanan Surakarta Hadiningrat. Berdasarkan bekal keahlian yang diberikan tersebut masyarakat kauman dapat menghasilkan karya batik yang langsung berhubungan dengan motif-motif batik yang sering dipakai oleh keluarga kraton. Disamping produk batik, kampung batik Kauman juga dilingkupi suasana situs-situs bangunan bersejarah berupa bangunan rumah joglo, limasan, kolonial dan perpaduan arsitektur Jawa dan Kolonial. Bangunanbangunan tempo dulu yang tetap kokoh menjulang ditengah arsitektur modern pusat perbelanjaan, lembaga keuangan (perbankan dan valas), homestay dan hotel yang banyak terdapat disekitar kampung Kauman (Danarti, K, 1996 )

Secara fisik Kauman didominasi dengan bangunan rumah tinggal di samping terdapat beberapa bangunan fasilitas sosial dan fasilitas umum. Beberapa di antara bangunan tersebut merupakan bangunan kuno. Bangunan tersebut sebenarnya menarik namun terabaikan sehingga menjadi tidak terawat. Secara keseluruhan fisik kampung juga khas dengan adanya lorong-lorong dan di beberapa tempat terdapat bangunan kolonial (percampuran arsitektur lokal dan 
asing). Ada fenomena, karena tuntutan kehidupan, kini, menyebabkan kondisi Kauman menjadi tidak spesifik. Tujuan dari penelitian ini adalah mencari keragaman perubahan ruang yang terjadi pada rumah lama di Kauman dan faktor apa yang mempengaruhi. Metode yang digunakan adalah deskriptif kualitatif dengan pencarian data secara survey dan wawancara terhadap 7 kasus rumah.

\section{TINJAUAN PUSTAKA Perubahan}

Perubahan adalah suatu proses yang mengakibatkan keadaan sekarang berbeda dengan keadaan sebelumnya dan perubahan itu sendiri bisa berupa kemunduran dan bisa berupa kemajuan. Terdapat 2 rumusan definisi perubahan, yang pertama sebagai perbedaan keadaan yang berarti dalam unsur masyarakat dibanding dengan keadaan sebelumnya; Dan yang kedua, sebagai proses perkembangan dari waktu ke waktu yang membawa perbedaan yang berarti dalam struktur dan fungsi. Setiap perubahan yang ditempatkan realitas sosial mau tidak mau akan menyentuh tiga aspek unsur dasar yaitu manusia, waktu dan tempat. Dengan kata lain, setiap perubahan yang berarti akan digerakkan oleh manusia, dalam unit waktu tertentu dan lingkungan tertentu, maka konsekuensinya adalah setiap kajian perubahan tidak bisa mengabaikan semua aspek (Hendropuspito 1989).

Perubahan adalah proses diffusi terkait dengan penyebar luasan gagasan, ide-ide dan keyakinan maupun hasil budaya yang berupa fisik. Hal penting terkait dengan proses perubahan adalah : Inovasi yaitu suatu ide baru, Komunikasi yaitu interaksi yang berlangsung sewaktu melontarkan suatu ide baru (baik secara langsung maupun tidak langsung), sistem sosial dimana individuindividu bertindak dalam kaitanya dengan inovasi tertentu, unsur waktu : kemampuan orang untuk menerima inovasi baru. Margono slamet (dalam Hendropuspito, 1989) dalam konsepsinya menyatakan terdapat kekuatan yang mempengaruhi perubahan, yaitu kekuatan pendorong (motivational forces), kekuatan yang terdapat pada diri sendiri maupun masyarakat yang bersifat mendorong orang-orang untuk berubah. Oleh karena itu tanpa adanya kekuatan tersebut orang akan mempunyai keenganan untuk berubah.

Terdapat 2 faktor penyebab perubahan , yaitu Internal yang meliputi pengisian waktu luang yang dilakukan oleh individu-individu, derajat pendidikan yang diperoleh, aktivitas dalam masyarakat, suasana rumah tangga, skill dan kreativitas dan Hidup dalam keadaan yang lebih baik. External yang meliputi : ketidakpuasan terhadap situasi yang ada, karena itu ada keinginan untuk mendapatkan situasi yang lain, adanya pengetahuan tentang perbedaan antara yang ada dan yang seharusnya bisa ada, adanya tekanan dari luar seperti kompetisi atau keharusan untuk menyesuaikan diri dengan perubahan yang terjadi di luar dan kebutuhan dari dalam masyarakat untuk mencapai efisiensi dan peningkatan produktifitas (Astrid S. Susanto. 1999)

Berbagai perubahan itu biasanya meliputi, perubahan struktural dimana perubahan ini meliputi bergesernya cara pandang individu terhadap struktur yang ada dalam masyarakat atau memang menurunnya kemampuan struktur untuk mempertahankan berbagai nilai guna pada masa silam karena harus dihadapkan pada dinamika tuntutan dan dinamika masyarakat. Kemudian perubahan pada pola-pola kelakuan. Ketika struktur mengalami pergeseran maka berbagai bentuk aktivitas yang menyertainya pun mengalami perubahan yang sesuai dengan berbagai kelakuan yang baru dan relevan dengan perubahan yang terjadi. Lalu perubahan itu juga akan menimpa nilai-nilai sosial yang berlaku di dalam masyarakat (Hendropuspito, 1989).

\section{Ragam dan fungsi ruang pada rumah jawa}

Menurut K. Ismunandar.R, 1993 ragam dan fungsi ruang pada rumah Jawa adalah sebagai berikut :

\section{Pendopo}

Letaknya yang terdapat pada bagian paling depan dari sebuah rumah tinggal, fungsi sebuah pendopo adalah tempat untuk bersosialisasi dengan keluarga, kerabat maupun tetangga, demikian juga sebuah pendopo tidak hanya sekedar sebuah tempat tetapi mempunyai makna yang lebih dalam yakni mengaktualisasi satu bentuk kerukunan antara si penghuni dengan masyarakat sekitarnya/kerabatnya. 


\section{Pringgitan}

Bentuknya seperti serambi, ruang ini berfungsi sebagai tempat pementasan wayang kulit (ringgit). Suasana yang tercipta adalah agak remang-remang dan mengandung mistis.

3. Dalem

Bangunan ini merupakan ruang keluarga, tempat tinggal orang tua dan anak-anak perempuan, serta tempat menyimpan harta benda yang berharga. Berfungsi sebagai ruang keluarga yang bersifat pribadi. Suasana di dalamnya tenang dan berwibawa. Pintu dan jendela pada dalem dipasang simetris.

4. Gandhok

Bangunan memanjang yang terletak disebelah kiri, sebelah kanan, dan bagian belakang bangunan utama (dalem) yang disebut dengan gandhok. Bangunan yang terletak disebelah kiri dalem disebut gandhok kiri berfungsi untuk tidur kaum laki-laki, dan yang terletak disebelah kanan disebut gandhok kanan berfungsi untuk tempat tidur kaum perempuan.

\section{Senthong}

Senthong merupakan tiga buah kamar yang berjajar terdiri dari: a). senthong kiwo /kamar bagian kiri, b). senthong tengah dan c). senthong tengen/ kamar bagian kanan. Senthong tengah berfungsi untuk tempat pemujaan terhadap Dewi Sri atau Dewi Kesuburan dan kebahagiaan rumah tangga. Senthong tengen (kamar bagian kanan) berfungsi untuk kamar tidur tuan rumah. Senthong kiwo (kamar bagian kiri) berfungsi sebagai tempat menyimpan senjata dan barang-barang keramat.

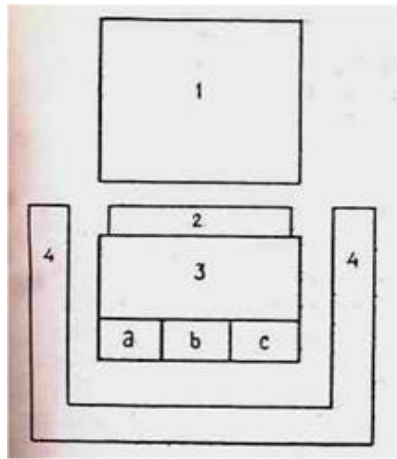

Gambar 1. Tata ruang tradisional Jawa Sumber : K. Ismunandar. R, 1993

\section{METODE PENELITIAN \\ Metode Pengumpulan Data}

Pengumpulan data dilakukan dengan metode survey. Metode ini dilakukan dengan wawancara, observasi langsung dan dokumentasi. Wawancara dilakukan kepada narasumber terhadap data yang belum terungkap dilapangan. Metode Observasi Langsung dilakukan guna mendapatkan data secara langsung bagaimana kondisi fisik yang ada tanpa adanya suatu rekayasa tertentu. Terdapat 7 rumah kuno di Kauman yang diambil sebagai kasus.

\section{Alat Penelitian}

Alat yang digunakan untuk pengumpulan data adalah: kamera, alat tulis / alat gambar, kertas gambar, komputer, gambar, dan meteran

\section{Variabel Penelitian}

a) Tata Ruang

b) Fungsi Ruang

c) Faktor yang berpengaruh terhadap perubahan

\section{Metode Analisis Data}

Penggunaan metode pengumpulan data diatas akan menghasilkan data mentah, kemudian diolah dengan cara membandingkan antara rumah lama (asli) dengan perubahan fungsi yang terjadi. Cara yang dilakukan dengan membuat gambar tata ruang lama dan tata ruang baru kemudian membuat kesimpulan.

\section{TEMUAN PENELITAN DAN PEMBAHASAN}

Persamaan ruang terjadi antara ruang untuk rumah tradisionl Jawa dengan ruangruang yang terdapat di Kauman Surakarta. Di Kauman terdapat juga pendhapa, pringgitan, dalem, senthong dan juga gandhok yang mempunyai batas teritori tata fisik luasan lahan mulai dari jalan depan sebagai jalan utama yang di tandai adanya pintu masuk regol ngarep, sampai menembus jalan lingkungan dengan dilengkapi regol butulan sebagai pintu service.

Merupakan manifestasi simbolik dari nilai kosmologi dan simbolisme center dengan pola closed ended plan, yaitu simetri keseimbangan yang berhenti pada suatu ruang senthong. Sistem hirarki memperlihatkan adanya gradasi berurut dari depan ke belakang dengan derajat 
kepentingan pada peran fungsional, formal dan simbolisnya. Sistem peruangan senthong; dalem, peringgitan, dan pendopo berada pada satu as-garis lurus, ruang sentong pada hirarki tertinggi berada di bagian dalam dan paling sakral. Secara fisik menggunakan kontruksi atap Joglo dan Limasan, dengan penutup atap sirap dan genting. Tiang kayu sebagai struktur pendukungnya, dinding dengan pasangan satu batu, lantai menggunakan tegel warna. Secara keseluruhan karakteristik visual rumah ulama merupakan citra spesifik sebagai identitas warisan budaya setempat, yang dapat menjadi indikator dalam menggali potensi sejarah masa lalu, serta kemungkinan dalam mengantisipasi perkembangannya di masa mendatang. Dengan demikian akan membentuk katagorisasi spasial dimana aspek karakteristik visual setiap ruang mempunyai klasifikasi dan makna yang spesifik, sehingga akan berbeda dengan bangunan rumah lainnya.

\section{Kasus 1}

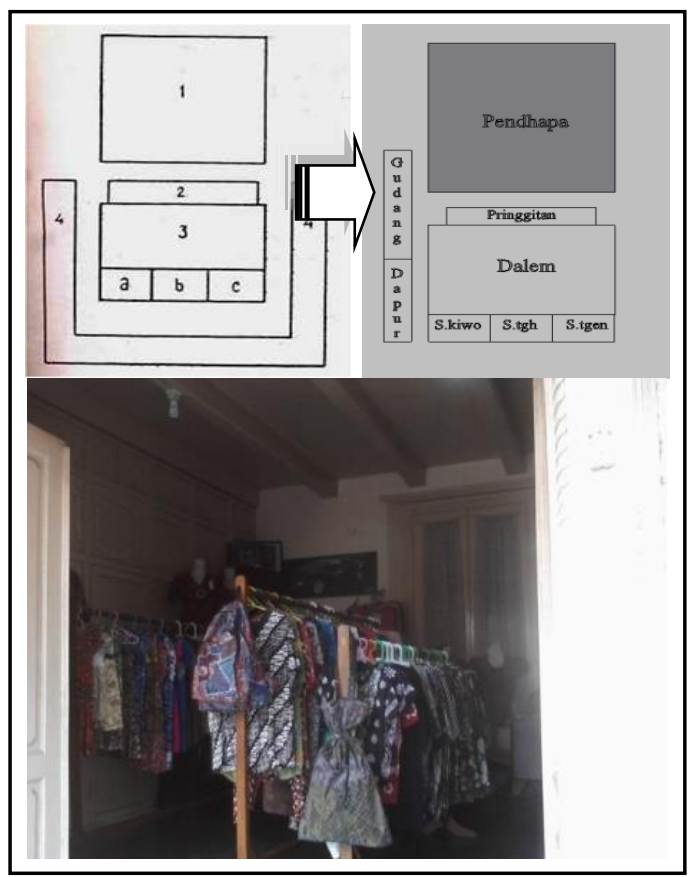

Gambar 2. Perubahan Fungsi pada Kasus 1 Sumber : Analisa Penulis, 2010

Pada kasus pertama, sedikit sekali terjadi perubahan fungsi ruang. Perubahan hanya terjadi di bagian gandhok menjadi gudang dan dapur. Tetapi seiring perubahan waktu, menurut pemilik rumah itu, yaitu Ibu Fitri, gudang dialih fungsikan lagi menjadi showroom batik karena posisi yang terletak dipinggir jalan. Kemudian gudang diletakkan diatasnya, yaitu lantai 2 dari showroom batik tersebut. Adapun faktor penyebab terjadinya perubahan fungsi ruang dari gudang menjadi showroom batik, antara lain, karena letak yang strategis, melestarikan kebudayaan batik dan kebutuhan ekonomi (wawancara langsung Ibu Fitri, sebagai pemilik rumah).

\section{Kasus 2}

Pada kasus 2, bentuk denah masih sama dengan denah rumah jawa, tidak menggalami perubahan tata letak tetapi juga menggalami perubahan fungsi ruang, yaitu perubahan dari fungsi asli pendhapa menjadi showroom batik. Faktor penyebabnya juga sama dengan kasus pertama,yaitu letak pendhapa yang berada paling depan dan yang paling dekat dengan jalan menjadikan pendhapa dapat dilihat langsung dari jalan.

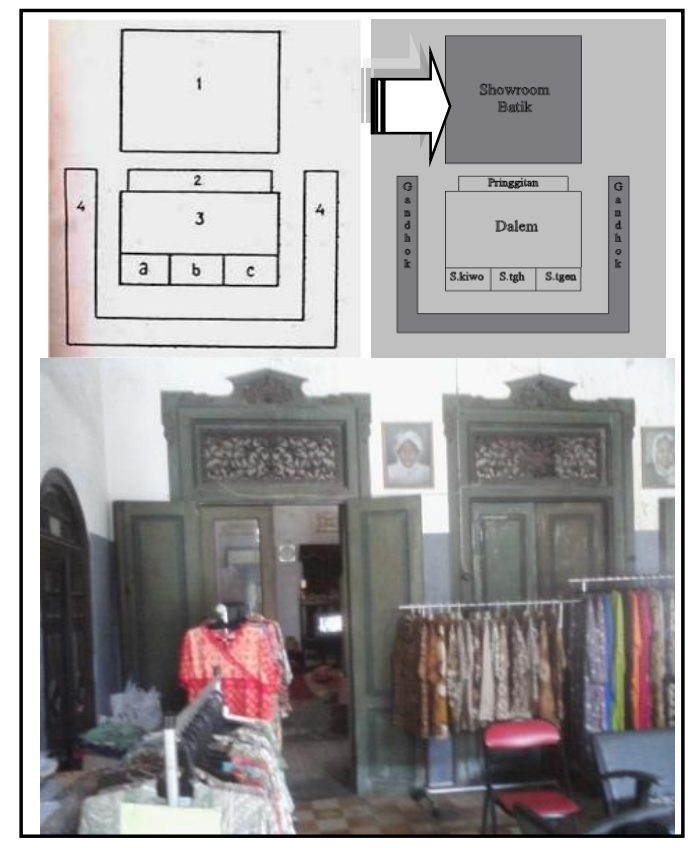

Gambar 3. Perubahan Fungsi pada Kasus 2 Sumber : Analisa Penulis, 2010

Sehingga apabila dijadikan sebagai tempat usaha mempunyai prosentase paling bagus dari pada penggunaan ruang lain. Apalagi batik merupakan ciri khas dari kampung Kauman sendiri yang sudah turun menurun, jadi tidak ada ruginya perubahan pendhapa menjadi showroom batik, sambil melestarikan budaya batik yang sempat di klaim oleh negara tetangga, ucap pemilik rumah Bp. Ridwan. 


\section{Kasus 3}

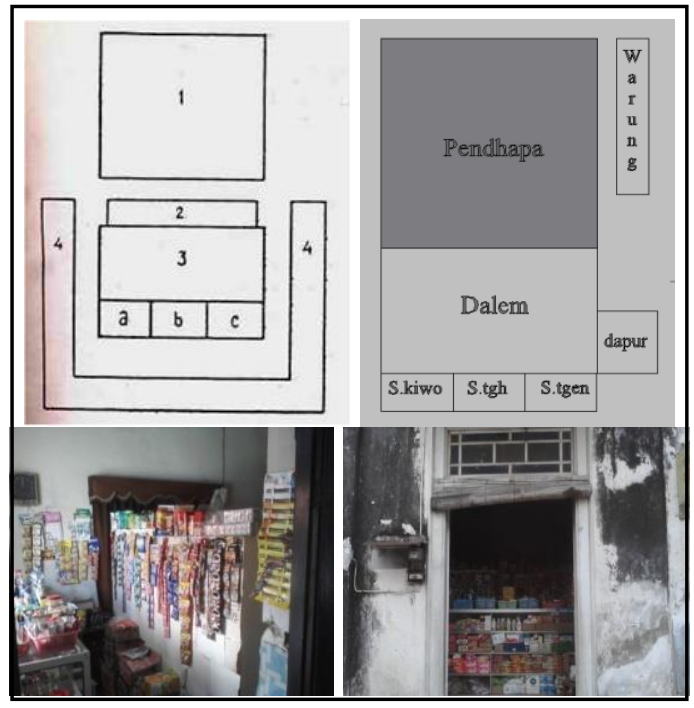

Gambar 4. Perubahan Fungsi pada Kasus 3 Sumber : Analisa Penulis, 2010

Kasus ke-3, disinilah mulai terjadi perbedaan bentuk denah dari rumah Jawa. Kalau di organisasi ruang rumah Jawa, antara pendhapa dan dalem terdapat satu ruang yaitu pringgitan. Tetapi di bentuk organisasi ruang yang saya temukan pada survey 2010, pringgitan itu tidak ada. Kemudian ruang yang dialih fungsikan adalah gandhok. Berubah fungsi menjadi warung yang sempit, dengan banyak sekali jajanan anak kecil dan kebutuhan rumah tangga. Faktor penyebab utama adalah ekonomi. Dengan dibukanya warung diharapkan menambah income penghasilan keluarga, tutur Bp.Anto selaku pemilik rumah.

\section{Kasus 4}

Perubahan cukup mencolok terjadi pada kasus ke-4, yaitu tidak adanya ruang gandhok. Bangunan masih bercirikan bangunan tradisional jawa,yang dilihat dari organisasi ruang masih cukup komplit. Untuk gandhok si pemilik sendiri juga tidak tahu, apa itu gandok dan fungsinya, karena rumah itu baru dibeli saja dibeli dari pemilik lama. Fungsi ruang yang dialih fungsikan adalah ruang tamu. Ruang yang seharusnya ruang tamu itu dijadikan menjadi tempat penjualan buku, karena untuk mengikuti perkembangan zaman dan kompetisi usaha, kata Bp. Sarwono.

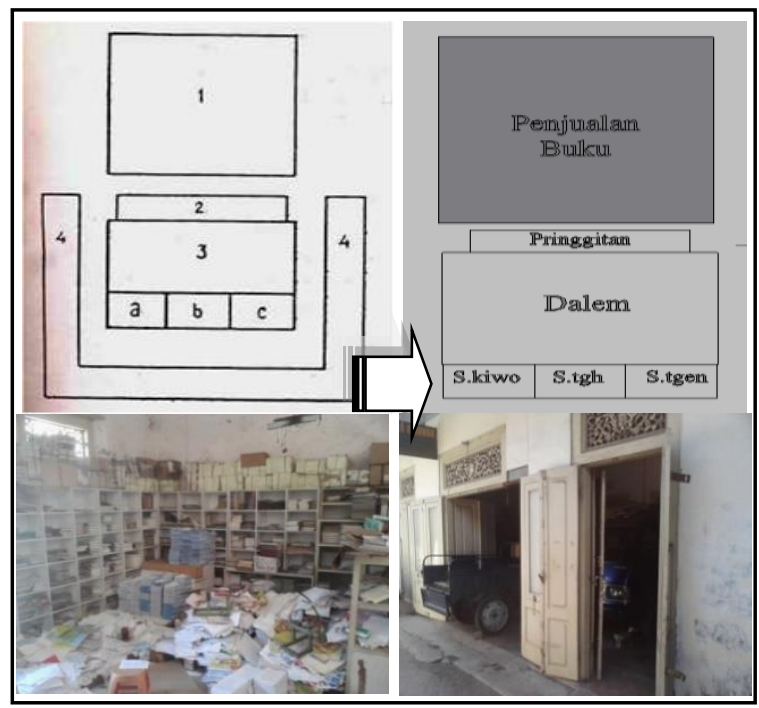

Gambar 5. Perubahan Fungsi pada Kasus 4 Sumber : Analisa Penulis, 2010

\section{Kasus 5}

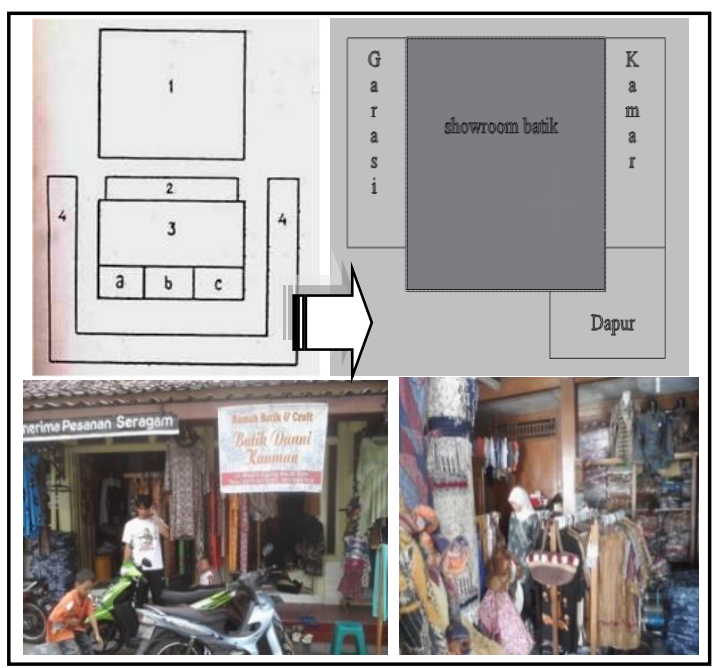

Gambar 6. Perubahan Fungsi pada Kasus 5 Sumber : Analisa Penulis, 2010

Perubahan sangat drastis terlihat pada kasus ke-5, organiasasi ruang sangat sederhana, terlihat hanya 4 ruang. Tidak ada pendhapa, pringgitan, dan senthong. Organisasi ruang ini sudah mengacu pada pola organisasi ruang untuk menitik beratkan pada usaha yang dijalani dan sudah cenderung ke modern. Kamar terletak di depan untuk memantau aktivitas usaha dan dapur sebagai penyokong aktivitas usaha sehari-hari, walaupun untuk makan sering beli diluar dari pada masak sendiri, kata pemilik rumah, Sdr.Sidiq Pramono. 


\section{Kasus 6}

Ada beberapa ruangan yang dialih fungsikan sebagai showroom maupun dagang. Tapi pada kasus ke- 6 ini berbeda dari kasus-kasus sebelumnya, yaitu satu ruangan mempunyai dua fungsi. Ruang yang dialih fungsikan adalah pendhapa menjadi showroom batik dan mempunyai fungsi lain yaitu pada waktu-waktu tertentu (jum'at) showroom batik ini dijadikan sebagai tempat pengajian. Pengaplikasiannya adalah batikbatik yang ada di showroom tersebut dipindahkan dulu ke ruang dalem. Faktor perubahan fungsi ruang tersebut adalah melestarikan budaya.

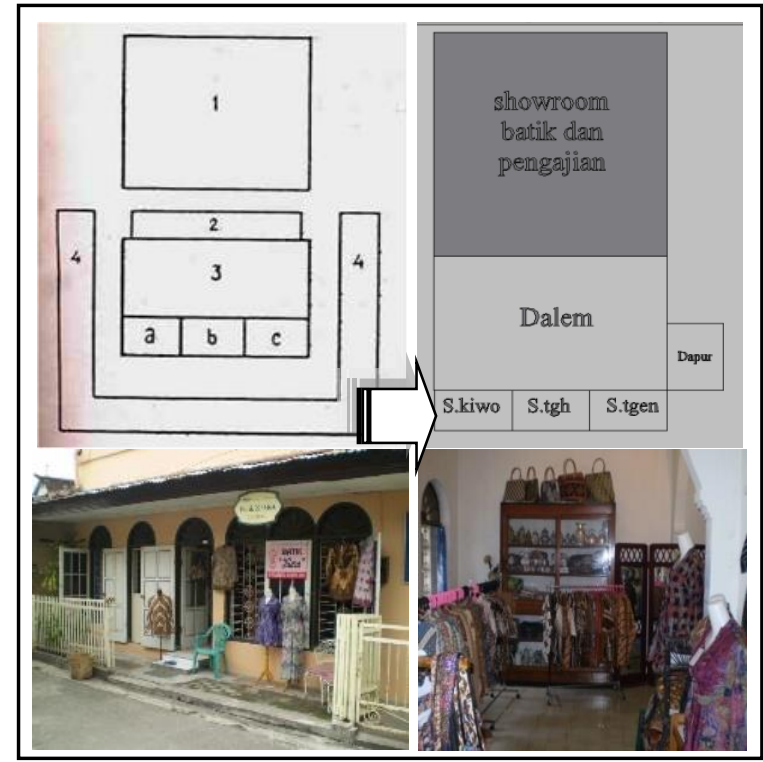

Gambar 7. Perubahan Fungsi pada Kasus 6 Sumber : Analisa Penulis, 2010

\section{Kasus 7}

Pada kasus yang terakhir terdapat alih fungsi dari ruang tamu menjadi persewaan buku. Tidak ada gandhok maupun pringgitan, senthong pun yang biasa terletak lurus ditengah, dipindah posisikan menjadi berderet disamping, jadi tidak ada senthong tengah, kiwo dan tengen. Adapun faktor perubahan dari pendhapa menjadi rental buku yaitu, pola pikir pemilik rumah ingin membuat maju warga sekitar dan perkembangan usaha, kata pemilik rumah lbu. Farid Hidayah sebagai pendatang.

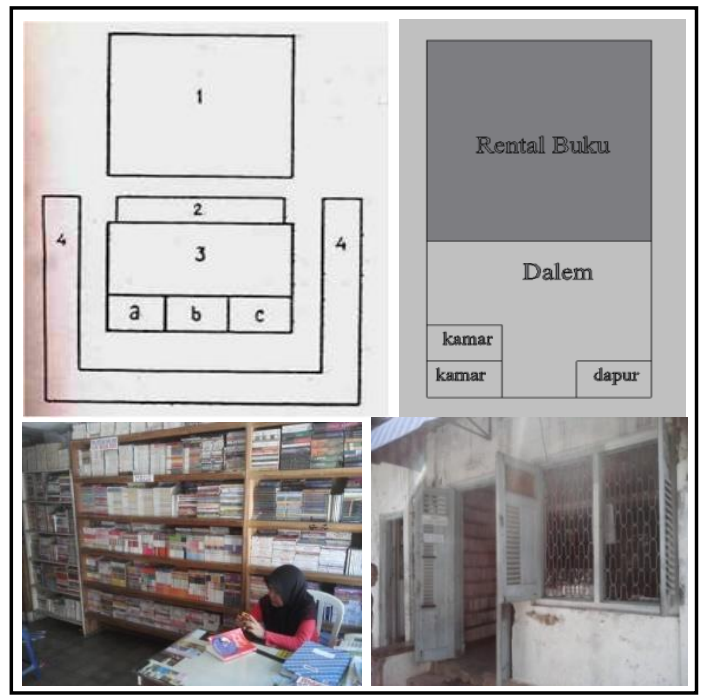

Gambar 8. Perubahan Fungsi pada Kasus 7 Sumber : Analisa Penulis, 2010

Dari hasil observasi dan wawancara maka ditemukan adanya jenis perubahan ruang seperti pada Tabel 1.

Tabel 1. Jenis Perubahan Ruang

\begin{tabular}{|l|c|l|c|l|c|c|c|}
\hline & Kasus 1 & Kasus 2 & Kasus 3 & Kasus 4 & Kasus 5 & Kasus 6 & Kasus 7 \\
\hline Pendopo & $\checkmark$ & $\begin{array}{l}\text { Showroom } \\
\text { batik }\end{array}$ & $\checkmark$ & $\begin{array}{l}\text { Penjualan } \\
\text { buku }\end{array}$ & $x$ & Pengaji-an & $\begin{array}{l}\text { Rental } \\
\text { buku }\end{array}$ \\
\hline pringgitan & $\checkmark$ & $\checkmark$ & $x$ & $x$ & $x$ & $x$ & $x$ \\
\hline Dalem & $\checkmark$ & $\checkmark$ & $\checkmark$ & $\checkmark$ & $\begin{array}{l}\text { Showroom } \\
\text { batik }\end{array}$ & $\checkmark$ & $\checkmark$ \\
\hline sentong & - & $\checkmark$ & $\checkmark$ & - & kamar & $\checkmark$ & kamar \\
\hline gandhok & gudang & $\checkmark$ & Warung & $x$ & garasi & $x$ & $x$ \\
\hline dapur & $\checkmark$ & $\checkmark$ & $\checkmark$ & $\checkmark$ & $\checkmark$ & $\checkmark$ & $\checkmark$ \\
\hline
\end{tabular}

Sumber : Analisa Penulis, 2010

Sedangkan faktor perubahan ruang dapat dilihat pada tabel 2.

Tabel 2. Jenis Perubahan Ruang

\begin{tabular}{|l|r|r|r|r|r|r|r|r|}
\multicolumn{1}{c|}{} & \multicolumn{9}{c|}{ Internal } & \multicolumn{5}{c|}{ Eksternal } \\
\hline & A & B & C & D & A & B & C & D \\
\hline Kasus 1 & $\checkmark$ & & $\checkmark$ & $\checkmark$ & & & $\checkmark$ & $\checkmark$ \\
\hline Kasus 2 & $\checkmark$ & $\checkmark$ & & & & & $\checkmark$ & $\checkmark$ \\
\hline Kasus 3 & & $\checkmark$ & & $\checkmark$ & & & & $\checkmark$ \\
\hline Kasus 4 & & & $\checkmark$ & $\checkmark$ & & $\checkmark$ & & \\
\hline Kasus 5 & & & $\checkmark$ & & & $\checkmark$ & & \\
\hline Kasus 6 & & $\checkmark$ & & $\checkmark$ & & $\checkmark$ & & $\checkmark$ \\
\hline Kasus 7 & & $\checkmark$ & $\checkmark$ & & & $\checkmark$ & $\checkmark$ & \\
\hline
\end{tabular}

Sumber : Analisa Penulis, 2010

Bersasarkan data diatas dapat di simpulkan prosentase yang dominan menjadi penyebab perubahan fungsi rumah sebagai berikut:

1. Internal :
a. Suasana keluarga
$28.57 \%$
b. Faktor ekonomi
$57.14 \%$
c. Skill
$57.14 \%$
d. Warisan keluarga
$28.57 \%$
e. Derajat pendidikan
$14.28 \%$
f. Coba-coba 
2. Eksternal :
a. Bujukan orang lain
$14.28 \%$
b. Perkembangan usaha : $57.14 \%$
c. Letak strategis
$: 42.85 \%$
d. Melestarikan budaya : $42.85 \%$
e. Usaha sampingan : $14.28 \%$

Jadi prosentase terbesar (faktor dominan) dari masing-masing faktor penyebab perubahan adalah: faktor Internal : faktor ekonomi dan skill dengan $57.14 \%$ dan Eksternal: perkembangan usaha dengan $57.14 \%$ dan prosentase perubahan ruang terbesar adalah sebagai berikut :
a. Pendopo : $66.67 \%$
b. Pringgitan : $0 \%$
c. Dalem : $16.67 \%$
d. Sentong : $0 \%$
e. Gandhok : $50 \%$
f. Dapur : $0 \%$

\section{KESIMPULAN}

Rumah tinggal orang Jawa (rumah kuno di Kauman) selalu memperhatikan keselarasan dengan kosmosnya dalam pengertian selalu memperhatikan dan menghormati potensi-potensi tapak yang ada disekitarnya. Dari beberapa kasus yang telah diperoleh, hanya beberapa ruang yang mengalami perubahan fungsi ruang. Ruangruang tersebut merupakan ruang yang letaknya disamping jalan atau yang dekat dengan jalan. Dikarenakan kemudahan pencapaian dari jalan menuju aktivitas. Bisa dilihat dari perubahan fungsi ruang yang terjadi, meliputi pendapa dengan prosentase paling besar dengan $\mathbf{6 6 . 6 7 \%}$, kemudian diikuti gandok dengan prosentase $\mathbf{5 0} \%$. Disamping dari jenis ruang diatas juga terdapat faktorfaktor penyebabnya yang meliputi faktor internal dan faktor eksternal. Di dalam faktor internal prosentase terbesar adalah skill dan kebutuhan ekonomi yang mempunyai kedudukan yang seimbang yaitu $29 \%$. Kemudian untuk faktor eksternal didominasi untuk perkembangan usaha yang mencapai $37 \%$, kemudian diikuti letak yang strategis dan melestarikan budaya batik dengan prosentase sebesar $\mathbf{2 7 \%}$.

\section{SARAN}

Kampung Kauman merupakan kampung lama dengan bentuk fisik yang unik. Lokasinya yang dekat dengan Jalan Slamet Riyadi menjadikan kampung ini memiliki prospek ekonomi yang sangat besar. Perubahan fungsi pada rumah-rumah yang terdapat di kampung ini secara tidak langsung juga merubah bentukan fisiknya. Berjalannya waktu menyebabkan tidak terkontrolnya adanya perubahan besar, oleh sebab itulah dalam rangka pelestarian kawasan di harapkan pemerintah kota mulai menerapkan guideline atau standard dalam perubahan rumah terkait dengan perubahan secara fisik terutama fasad.

\section{DAFTAR PUSTAKA}

Astrid S. Susanto. 1999 : 157-162. Pengantar Sosiologi dan Perubahan Sosial. Bina Cipta.

Danarti, K, 1996, Perubahan Bentuk Tata Ruang Lingkungan Permukiman di Kauman Surakarta, Thesis S2 Teknik Arsitektur, UNDIP

Hendro Puspito, 1989, Sosiologi Sistemik, Jogjakarta: Kanisius

K. Ismunandar.R, 1993, Joglo Arsitektur Rumah Tradisional Jawa, Dahara Press, Semarang,.

Wiwik Setyoningsih, 1999, Sistem Spasial Rumah Ketibdi Kauman Surakarta, Thesis S2 IImu Teknik Jurusan Arsitektur, UGM Yogyakarta 